\title{
A Compromised Commerce with East India: Lucien Bonaparte's La Tribu indienne, ou Édouard et Stellina (I799)
}

$I^{\mathrm{N}}$ N EARLY I799 AT THE AGE OF TWENTY-FOUR, LUCIEN BONAPARTE (I775I 840) published an exotic, sentimentalist first novel, La Tribu indienne, ou Édouard et Stellina. ${ }^{\mathrm{I}}$ A native from Corsica who had been educated in France, Lucien Bonaparte had not yet traveled abroad, but Corsica's recent struggle for independence from the Genovese Republic and its eventual conquest by France made the island a microcosm of local revolts against external powers, and certainly radicalized a young Lucien. La Tribu indienne, a colonial fiction set on the island of Ceylon (today's Sri Lanka) relates "le commerce des Indes" through the story of Édouard Milford, a young Englishman sent to Java by his merchant father. ${ }^{2}$ Stranded in Ceylon where the Bedas tribe attacks his shipmates, Milford seduces and abandons the native woman who saves him, Stellina, the daughter of a tribal chief. With the exception of Cecilia Feilla's critical edition, biographers and critics have dismissed the novel as a failed, or unimportant work, or confined themselves to an aesthetic reading of the text as proto-Romantic, disconnected from any colonial and imperial context. ${ }^{3}$ Yet the text is

I. Bonaparte, La Tribu indienne, ou, Édouard et Stellina, ed. Cecilia A. Feilla (London: Modern Humanities Research Association Critical Texts, 2006). References are to this edition and hereafter will be noted parenthetically within the text.

2. Bonaparte, La Tribu indienne, 27. For earlier examples of French colonial fictions, see Fictions coloniales du XVIIIe siècle: Ziméo. Lettres africaines. Adonis, ou le bon nègre, anecdote coloniale, ed. Youmna Charara (Paris: L'Harmattan, 2005).

3. "une larmoyante histoire dans le goût de l'époque" for Gilbert Martineau, Lucien Bonaparte, prince de Canino (Paris: Éditions France-Empire, I989), 98; "cette œuvre indigeste" for Théodore Iung, Lucien Bonaparte et ses mémoires, 1775-1840 (Paris: G. Charpentier, I882-83), I:275-76; "an oddly prophetic novel" for Marcello Simonetta and Noga Arikha, Napoleon and the Rebel: A Story of Brotherhood, Passion and Power (New York: Palgrave Macmillan, 20II), 6I. Marie Teresa Caracciolo proposes a more nuanced literary analysis but does not address the question of colonialism. 
symptomatic of conflicting ideological forces cemented into the narrative: it bears the trace of Lucien's readings of Enlightenment authors and of his subsequent rallying behind his brother Napoleon's ambition to recapture a lost colonial glory with the Egyptian expedition he began in I798, mostly welcome and understood in France as a strategy to block England's trade routes toward India. ${ }^{4}$ The year I80 s saw the departure of the expedition of Charles Leclerc (Pauline Bonaparte's husband, Lucien's brother-in-law) to reconquer Saint Domingue, a colony that was still French, but de facto largely independent under Toussaint Louverture's governorship. Because of England's declaration of war, French policy dictated the imperative to defend the colonies against a British takeover. ${ }^{5}$ In what follows, I argue that Lucien Bonaparte's novel is an exemplary text for illuminating France's compromised position at the turn of the nineteenth century, caught between the Déclaration des droits de l'homme et $d u$ citoyen and the ambition to recapture lost colonies (or gain new ones) the better to compete with England.The novel posits an enlightened, post-revolutionary France against a heartless, mercantile, and rapacious Britain. ${ }^{6}$ A close reading reveals that Lucien Bonaparte captured the anti-colonialism that Diderot anonymously inserted in Guillaume-Thomas Raynal's famed Histoire philosophique et politique des établissements et du commerce des Européens dans les deux Indes (I780). ${ }^{7}$ Lucien Bonaparte channeled sentiments against British imperialism

Her exhibition catalogue entry on the novel itself is a synopsis of the book. Caracciolo and Isabelle Mayer-Michalon, 1775-1840: Lucien Bonaparte, un homme libre. Exposition présentée au Palais Fesh-musée des Beaux-Arts du 26 juin au 27 septembre 2010 (Ajaccio, FR: Palais Fesh-musée des Beaux-Arts, 20I0), II7-2I, I 44-45.

4. See Yves Benot, La Démence coloniale sous Napoléon (Paris: La Découverte, 2006).

5. Benot, Les Lumières, l'esclavage, la colonisation (Paris: La Découverte, 2005), 264-7I. According to Simonetta and Arikha, Lucien "had not been an enthusiast of the SaintDomingue expedition ... the expedition was a debacle. The French army was decimated by yellow fever. Général Leclerc, Pauline's husband and Lucien's friend, who was the governor of the island, was one of those who later would die in the epidemic." Napoleon and the Rebel, IO2-3. Hippolythe Jouberthon also died: he was the husband of Alexandrine, with whom Lucien had fallen in love in Paris while she was waiting to leave for SaintDomingue. His death allowed them to marry, a love marriage that Napoleon sought to prevent and refused to recognize. Simonetta and Arikha, Napoleon and the Rebel, II3.

6. The novel is evidence, therefore, that the practice of "nationalization," which Srinivas Aravamudan identified in the late eighteenth century, continued even after the French Revolution: "Nationalization resembles anti-imperialist political practice most effectively. It speaks the discourse of nationality and collectivity in the manner of the later eighteenth century. This discourse most resembles our present understanding of imperialism, inflected as it is by the long nineteenth century, and the decolonization debates of the short twentieth century." Aravamudan, Tropicopolitans. Colonialism and Agency. 1688-1804 (Durham, NC: Duke University Press, I999), 2 I.

7. Raynal, Histoire philosophique et politique des établissements et du commerce des Européens dans les deux Indes, vol. I, books I-4, ed. Anthony Strugnell, Rigobert Bonne, and Andrew Brown (Ferney-Voltaire, FR: Centre international d'étude du 
similar to Diderot's the better to promote alternative French civilizing practices. ${ }^{8}$ I argue that with La Tribu indienne, Lucien Bonaparte attempted to fictionalize the first chapters of Guillaume de Raynal's history of trade in East India by the Portuguese, the Dutch, and British, as a metatext for its sad tale of colonial exploitation: he drew both upon the facts (dates, names, maps) of Raynal's Histoire des deux Indes, ${ }^{9}$ and upon its interpretation of the highs and lows of Portuguese colonial conquest, the rise of rival Dutch colonialism, and British exactions in India, footnoting his novel with direct or indirect references to Raynal. ${ }^{10}$ The impact of Raynal's work extended beyond Lucien Bonaparte: it held tremendous importance for Germaine de Staël (I766-I8I7), Benjamin Constant (I767-I830), and François-René de Chateaubriand (I768-I848). His older brother Napoleon (I769-I82I) greatly admired Raynal and traveled with the Histoire des deux Indes during the Egyptian campaign. " Raynal's treatment of "la question coloniale" shaped the vision of the colonial question by this new, Romantic generation, of which Lucien Bonaparte is a representative, a generation who lived through the French and Haitian Revolutions, and their aftermath, the building of the First French Empire. ${ }^{12}$ While folding Raynal's history

XVIIIe siècle, 20Io). The three editions of the complete multi-volume work are now available via the University of Chicago's ARTFL project at https://artflsrvo3.uchicago.edu/philologic4/raynal. The now searchable text also features Diderot's contributions in red, a helpful color-coding.

8. See Feilla's introduction, La Tribu indienne, Io. On polyphony in the Histoire des deux Indes, see L'Histoire des deux Indes: réécriture et polygraphie, Studies on Voltaire and the Eighteenth Century, ed. Hans-Jürgen Lüsebrink and Anthony Strugnell, Studies on Voltaire and the Eighteenth Century series, no. 333 (Oxford: Voltaire Foundation, I995).

9. La Tribu indienne contains many specific geographic locations, which Lucien Bonaparte probably found in the increasingly detailed maps that accompanied Raynal's Histoire. They are accessible in Raynal, Tableaux, atlas et cartes de l'Histoire philosophique et politique des établissements et du commerce des Européens dans les deux Indes: Fac-similés des éditions de 1774 et 1780, ed. Anthony Strugnell, Rigobert Bonne, and Andrew Brown (Ferney-Voltaire, FR: Centre International d'étude du XVIIIe siècle, 20Io).

Io. There are sixteen footnotes in all: eight concern geo-historical facts; four are clarifications of botanical terms; four give "anthropological" information on local practices; and one is geographical. The direct reference to Raynal belongs to a historical note that gives Histoire des Deux Indes as the source of a quotation in the novel, the response of King Candi to the Dutch.

II. On Napoleon's early admiration for Raynal to whom he wrote when he was seventeen and met when he was twenty, see Andy Martin, Napoleon the Novelist (Cambridge: Polity Press, 2000) and Nada Tomiche, Napoléon écrivain (Paris: Armand Colin, I952), I4.

I2. How the fate of Santo Domingo was playing out in metropolitan politics and literature can be found in the Mercure de France (a journal founded by Fontanes, under Lucien's patronage and to which Chateaubriand contributed), which Yves Benot considers "le principal organe de presse du parti esclavagiste. En I802, il défend avec une extrême vigueur la régression bonapartiste ... La ligne générale du Mercure, c'est l'attaque permanente contre la philosophie des Lumières, la prétendue 'sagesse 
of commerce into a fictional frame, Lucien Bonaparte also strikingly preserved the sentimentality that Lynn Festa demonstrated as a key principle at work in the Histoire "to reel the world home, dissolving the distance between colonial devastation and the scene of metropolitan reading." ${ }^{13}$ As such, La Tribu indienne confirms the lasting legacy in France of what Festa termed "sentimental figures of empire" deployed to trigger sympathy for the victims of colonial enterprise and thereby "palliate the very inequities commerce sustains." ${ }^{14}$

The political confusion subtending the novel might explain why its author attempted to get rid of it. Indeed, the novel has a curious publication history or after-life: Lucien Bonaparte destroyed all copies soon after his participation in the Dix-huit Brumaire coup (November 9, I799) in support of his older brother Napoleon, who had named him Interior Minister in December I799. ${ }^{15}$ Whether the book's destruction was ordered by Napoleon himself is unclear, but the novel's devastating portrayal of colonial malpractice and lack of allegiance to a politics of conquest certainly jeopardized its author's political ambitions after the Dix-huit Brumaire coup. ${ }^{16}$ Lucien Bonaparte's equivocal post-revolutionary novel thus offers an intriguing paradigm for understanding the link between French Enlightenment thought and the emergence of the First Empire. Raynal's history of commerce, layered as it was with Diderot's textual interventions to critique colonialism, shaped

moderne." [the principal press organ of the pro-slavery party. In I802, it vigorously defends the Bonapartist regression ... The Mercure's editorial line is a permanent attack against the philosophy of the Enlightenment, the supposedly 'modern wisdom.'] Benot, La Démence coloniale, 193-96.

13. Festa, Lynn M, Sentimental Figures of Empire in Eighteenth-century Britain and France (Baltimore: John Hopkins University Press, 2006), 220.

I4. Festa thus concludes her illuminating analysis of Raynal: "The tear-filled eyes of Raynal's omnivoyant philosophe behold a globe united, not by commerce, but by the chimerical promise of a sentimental union intended to palliate the very inequities commerce sustains" (Sentimental Figures of Empire, 232).

I5. Only three copies survived that have been used for the critical edition published in 2006 by Cecilia Feilla.

I6. Interestingly, a year after Napoleon's death, the novel reappeared in I822 anonymously, allegedly translated from the work of Mistriss Helm [sic], with a new title, more suggestive of its Eurocentrism: Les Ténadares ou l'Européen et l'Indienne, traduit de l'anglais de mistriss Helm, auteur de la caverne de sainte Marguerite, par Mr. A. C., 2 vols. (Paris: Chaumeront aîné, I822), available in Gallica. It turns out the text is identical, except for the missing final dedication to Eléonore, Lucien's sister, and the substitution, "mon amie" instead of her name on the last page (2:2I2). My hypothesis is that this anonymized pseudo-translation attributed to Elizabeth Helme, a prolific Gothic author and translator who died in I8I6, was an undercover attempt to bring the novel back into print. Nine years after its author's death, the novel appeared one last time in Veillées littéraires illustrées, edited by Jean Bry (Paris: Hachette Livre - BnF, I849). Caracciolo signals a translation in German (I802, new edition I8I2), in Danish (I805); in Spanish (I9I6) and Italian (2006). Caracciolo and Mayer-Michalon, 1775-1840: Lucien Bonaparte, un homme libre, I45. 
colonial ideas between I790 and I820, and helps contextualize Napoleon's Egyptian campaign (I798-I80I). The vision laid out in the last chapter of Raynal's Book Four, entirely written by Diderot, and titled "Principes que doivent suivre les Français dans l'Inde, s'ils parviennent à y rétablir leur considération et leur puissance" [Principles that the French must follow in India, if they succeed in reestablishing their consideration and power] (emphasis added) remained on the horizon for both brothers and applicable to other continents. On the one hand, these principles read like a manifesto for tolerance, respect, freedom, justice, and humanity, a model for "Enlightenment cosmopolitans." On the other hand, Diderot ultimately did not/could not question the very principle of the right to conquer and exercise power over indigenous populations. Moreover, Diderot envisioned France as a model for what we could call "colonialisme éclairé." Lucien Bonaparte's novel helps capture the passage from this eighteenth-century vision of "colonialisme éclairé" (vs. mercantile colonialism) to the nineteenth century's global vision undergirding Napoleonic imperialism.

By interpreting the text as a "compromised commerce," I play upon the double meaning of both compromise (as conciliation and/or incrimination) and commerce (as relationships and/or trade). The story related in the novel is compromising (compromettante) because of its message, captured in the final lines, which contemporaries most often excerpted: "Heureux les pays sauvages inconnus aux nations policées de l'Europe et qui ne possèdent rien qui puissent attirer ses avides spéculateurs!" [Blessed are wild countries unknown to Europe's civilized nations and which possess nothing that can attract avid speculators!] (I I4) $\cdot^{18}$ Couched as a Beatitude ("Blessed are ..."), the anti-European spirit of these lines ran counter to Napoleon's imperial projects for Europe, a fact that likely justified getting rid of a novel that incriminated its author. ${ }^{19}$ The relationship between the two brothers was always a mix of mutual support and antagonism, admiration and resentment, punctuated by clashes of competing literary and political ambitions between Napoleon's aspirations as a writer and his military genius on the one hand, and, on the other, the "génie des arts" whom Lucien aspired to be. ${ }^{20}$ If at

17. As defined by Aravamudan in Tropicopolitans.

I8. Lucien Bonaparte's final address to "mon Eléonore," his sister to whom the book is dedicated, is separated from the text by a line, but precedes the word FIN [The End], a curious typographical placement that folds authorial intervention into the narrative, in the manner of the 'morale' at the end of fables.

I9. On Napoleon's wish to build Europe as an empire, see Frederick Cooper, Colonialism in question: Theory, Knowledge, History (Berkeley, CA: University of California Press, 2005).

20. On Napoleon's aspirations as an author in the years $1789-95$ (including an essay on happiness; a novel titled Clisson and Eugenie; and a Corsican novella), see Martin, Napoleon the Novelist, and Nada Tomiche, Napoléon écrivain, 19-23. Lucien Bonaparte was instrumental in reconstituting the Académie française in I800 and was elected in I803. See http://www.academie-francaise.fr/les-immortels/lucien-bonaparte. 
first sight the novel seemed so compromising as to explain its author's decision to eliminate all copies, I argue that the novel is instead compromised (compromis), in the sense that it makes questionable concessions throughout: its overt anti-colonialism covers up equivocal writing practices. These, I shall articulate using the literal and figurative valences of traffic, as political, sexual, religious, and literary 'trafficking.'

I also retain the double meaning (literal and figurative) of the term 'commerce,' as both trading material goods and social relations. The Robert Dictionnaire historique de la langue française confirms that, from its initial meaning, derived from the etymology cum [with] and merx, mercis [merchandise], the term acquired the more abstract sense of reciprocal relations in the seventeenth century. Though the figurative usage of commerce as interpersonal exchanges has now become an archaism, it is helpful to return to this meaning, which became standard in the seventeenth and eighteenth century. ${ }^{21}$ I will interrogate the representation of political commerce between nations, which the novel develops following Raynal's description, before I address sexual commerce, perhaps one of the least studied dimensions of Raynal's History, which is not just "philosophical and political," as its full title suggested, but which contains sexual exchanges as part of colonial practices. Next, religious commerce, embodied by the figure of the malevolent brahma, appears to serve a virulent anticlericalism. The fourth and last part of this essay considers a more metaphorical meaning of commerce as the trading back and forth of sentimental, libertine, and epic codes, with borrowings from famous European models. But this globalizing appropriation of genres and texts does not succeed, which intimates that the supposedly enlightened colonialism it seeks to promote is impossible. The notion of commerce I introduce in each section performs an ideological critique of the colonial project, a critique in turn undermined by the author's equivocal slippages.

Political Commerce: Ventriloquizing Raynal/Diderot's Histoire des deux Indes

Édouard's character condenses into a British masculine archetype what Raynal narrates over the course of his chapters on England in book 3, a book that was expanded and updated considerably from edition to edition to keep up with the quick pace of English conquest in India. In his presentation of Raynal's third book, Anthony Strugnell notes:

Les lecteurs français, ceux surtout qui ne s'étaient pas remis de la défaite cuisante de leur nation subie pendant la guerre de Sept Ans face à leur grande rivale dans la course à la domination globale, étaient avides

2I. Dictionnaire historique de la langue française (Paris: Dictionnaire Le Robert, I993), s.v. "commerce." 
des informations les plus précises, des analyses les plus averties sur les faits et gestes de ce pays apparemment irrésistible.

[French readers, especially those who had not recovered from their country's bitter defeat in the Seven Years' War against its greatest rival in the race to global domination, were thirsty for more precise information and informed analysis on all activities of this seemingly irresistible country. $]^{22}$

Strugnell adds an ulterior motive to this fascination: "la France, du moins dans sa partie la plus éclairée, n'avait pas perdu espoir de se refaire dans le sous-continent et de redorer son blason de colonisatrice" [France, at least in its most enlightened part, had not lost hope to turn herself around in the Indian subcontinent and re-gild her coat of arms as a colonial power.] $]^{23}$ In La Tribu indienne, Édouard becomes a foil for these French hopes of reconquest. Édouard stands in for England's greed, exploitation, and cruel authority as Raynal represents these characteristics particularly in chap. 38 - "Vexations et Cruautés commises par les Anglais dans le Bengale" [Humiliations and Cruelties Perpetrated by the English in Bengal]-a radical indictment of English abuse of power and inhumanity vis-à-vis the native Bengalese population. ${ }^{24}$ Diderot inserted a lengthy, ringing prosopopoeia in this chapter to give voice to the victims' indignation: "Et nous tristes jouets de votre cupidité; malheureux tour-à-tour, \& par votre tyrannie, \& par votre indifférence, vous nous traitez comme des esclaves tant que vous nous supposez des richesses; \& quand nous n'avons plus que des besoins, vous ne nous regardez même pas comme des hommes." [And we, sad toys of your cupidity; made unhappy in turn by your tyranny and your indifference, you treat us like slaves as long as you think we possess riches; but when we are left with only needs, you do not even see us as humans. ${ }^{25}$ English inhumanity toward the population under its domination, fueled by "une insatiable cupidité" [insatiable greed], is a leitmotiv in these chapters, behavior made worse and less comprehensible because of England's otherwise enlightened legislation. ${ }^{26}$

The tone is set when the novel opens with the character of gold-thirsty, old Milford who raises his son to be a merchant capitalist. At stake is the growth and transmission of his immense capital acquired "par le commerce des Indes" [by trade with the Indies] (27). In the first page of his novel, Lucien Bonaparte had introduced Édouard as perfectly molded by his merchant father into his

22. Strugnell, "Présentation du livre III," in Raynal, Histoire, vol. I, chap. 3, 237.

23. Strugnell, "Présentation du livre III," in Raynal, Histoire, vol. I, chap. 3, 237.

24. Raynal, Histoire, vol. III, chap. 38, 322-28.

25. Raynal, Histoire, vol. III, chap. 38, 326.

26. Raynal, Histoire, vol. III, chap. 38, 327. 
own image: "Ce n'était ni un homme aimable, ni un honnête homme, ni un citoyen, mais un marchand qu'il avait formé." [It was neither a loving man, nor an honest man, nor a citizen, which he had trained, but a merchant] (27). The English trader contrasts explicitly with three humanist and enlightened ideals to which France laid claim: the amiability of the knight, the honesty of the Renaissance man, and the patriotism of the Revolutionary citizen. In place of such values, England held capital, therefore capitalism, above humanity. Indeed, the father is not affected by his son's departure, the narrator tells us, as hopes of increasing his treasures thanks to the presence of his son as a faithful correspondent abroad trumped "les vulgaires sentiments de la nature" [the vulgar feelings of nature] (28). Ventriloquizing Raynal and Diderot's Histoire des deux Indes, La Tribu indienne does not so much enjoin "let us not colonize!" as a first reading might have us believe, but "let us not colonize this way- the British way." La Tribu indienne portrays an anti-imperialism-à l'anglaise that leaves the door open for an imperialism à la française. ${ }^{27}$ To put it differently and to quote Sunil Agnani, it is about "hating empire properly." ${ }_{28}$ In examining the "the limits" of Enlightenment anti-colonialism, Agnani asked "How did Diderot argue against empire?"29 On the one hand, Diderot conjured up a fantasy of "soft commerce" and "soft colonization" [doux commerce/douce colonization] or "consensual colonialism," where consent is central to deploying this trope of sweetness or douceur. On the other hand, Diderot displayed "a contrary set of passions or affects, namely those of ressentiment, revenge and anger-modes of address that are surprisingly prominent in a text ostensibly about European settlements and trading companies. ${ }^{30}$ Diderot responded to the perceived injustice of colonialism and slavery by including affect within an examination of commerce and history, Festa and Agnani argue. ${ }^{31}$ The juxtaposition within the text of daring apostrophes and rousing rhetoric with arguments in favor of a douce colonisation or "the fantasy of a noncoercive colonial encounter" ${ }^{\prime 2}$ certainly explains the appeal of a narrative for an entire generation of intellectual and political figures that includes the Bonaparte brothers.

27. Aravamudan insists on the dual aspect of Raynal's Histoire des deux Indes: "As a rich, encyclopedic source of both imperialist and anticolonial attitudes, the text serves as a synecdoche of colonialist representation. Fiery denunciations of Western imperialism, absolutism and religious intolerance, both at home and abroad, subsequently identified as the writings of Diderot, are juxtaposed with careful disquisitions by lesser known authors on the problems of colonial trade and suggestions for its improvement" (Tropicopolitans, 23). See also Festa's chapter "Global Commerce in Raynal's Histoire," in Sentimental Figures of Empire, 205-32.

28. Agnani, Hating Empire Properly. The Two Indies and the Limits of Enlightenment Anticolonialism (New York: Fordham University Press, 2013).

29. Agnani, Hating Empire Properly, I4.

30. Agnani, Hating Empire Properly, I4.

3I. Festa, Sentimental Figures of Empire, 206-7; Agnani, Hating Empire Properly, I4.

32. Agnani, Hating Empire Properly, 35 . 
In the end, even this nationalistic paradigm of a soft French colonization is under question: Édouard's violent death at the hand of a vengeful native, Cosmoë, to whom Stellina had been promised, does not disrupt the trade system so much as it sends a warning about its risks and the likelihood of human losses. Édouard's murderer, Cosmoë, figures resistance against exploitation, defense of native land, and defiance of all Europeans. As the novel comes to an end, he sends a warning, that of a revolt of the oppressed: "Et si malgré moi vous arrachez à la terre un peu d'or, il sera couvert de votre sang; et cette terre dont vous dévorez les entrailles, à son tour vous dévorera." [If, in spite of me, you tear out some gold from the earth, it'll be covered by your blood; and the earth, whose entrails you're devouring, will devour you in return] (II3). In contrast with the "metropolitan" Édouard, there is something of Aravamudan's "tropicopolitan" in this rebellious character, as the narrator grants him an agency and authority denied to Stellina, and rival to the European colonizers: Aravamudan coined "tropicopolitan" as "a name for the colonized subject who exists both as fictive construct of colonial tropology and actual resident of tropical space, object of representation and agent of resistance. In many historical instances, tropicopolitans - the residents of the tropics, the bearers of its marks, and the shadow images of more visible metropolitans - challenge the developing privilege of Enlightenment cosmopolitans." ${ }^{33}$ Contrary to Édouard's downfall_—“L'Europe le désavoue" [Europe disavow him], says Fuentes (II3) - Cosmoë is ennobled, in the sense of acting and speaking according to his own value system. Cosmoë emerges at the end of the novel as the least compromised and compromising character.

\section{Sexual Commerce in La Tribu indienne}

The core anecdote of the amorous encounter at the origin of Lucien Bonaparte's novel had been circulating since it appeared in seventeenth-century travel narratives and was made popular by Richard Steele's Spectator in I7I I under the title "Inkle and Yarico"; the tale is reprised in an anonymous adaptation published in $\mathrm{I} 778$ in the Bibliothèque des romans. Raynal, whose "mode of history writing" was to solicit the reader's sensibility, ${ }^{34}$ incorporated the anecdote into the section on Barbados in book 7 of Histoire des deux Indes: to explain the context of a slave uprising in Barbados, Raynal reports in a short paragraph the story of a young Englishman, part of a British crew who landed in Africa to capture slaves. As the natives raced to massacre them, he fled into the woods where he was rescued by an Amerindian woman who eventually led him back to his ship and embarked with him: "Dès qu'ils furent arrivés à la Barbade, le monstre vendit celle qui lui avait conservé la vie, qui lui avait donné son cœur, avec tous les sentiments et tous les trésors de l'amour." [As

33. Aravamudan, Tropicopolitans, 4.

34. Festa, Sentimental Figures of Empire, 220. 
soon as they arrived in Barbados, the monster sold her, she who had saved his life, who had given her heart, with all the feelings and treasures of love]..$^{35}$ The Englishman temporarily exchanged his own body for rescue under the guise of love but sold the body of the female native. Raynal qualified the betrayal as "ce monument infâme d'avarice et de perfidie" [this abject monument to cupidity and perfidy $].^{36}$ On the surface, the plot of La Tribu indienne upholds moral outrage against sexual exploitation; in reality, it profits from a libertine representation of female sexuality while seemingly being sympathetic to one token female character, Stellina. ${ }^{37}$ In consequence, as we will see, Stellina functions less as a fully formed character than as an (admittedly confusing) allegory, part Orientalized figure, part figure of victimhood.

When Lucien Bonaparte developed the story and transported its characters to Ceylon, he emphasized the general public disgrace that befalls the de-natured British protagonist, who disgusts even the Portuguese. In using the female body and his own body as a commodity, the merchant colonizer does not so much cross a line between moral and immoral behavior as he does espouse a capitalist end that justifies the means. For Julia V. Douthwaite, a Marxist interpretation best fits the logic of the tale, that of "economic forces dominating the intellect." ${ }^{8}{ }^{8}$ I agree with Douthwaite that "the novel reads as a cautionary tale about capital and the brash new modes of attaining it - issues that were certainly in the air in post-revolutionary France. ${ }^{\prime 39}$ Sexual commerce in the novel is about sexual capital: on the one hand, the native female body, on the other the colonizer's deceptive good looks. Édouard first sees Stellina as a sleeping body: as the male gaze wanders, the narrative multiplies ellipses, typographically notable as four dots

35. Raynal, Histoire des deux Indes, vol. V, chap. I4, I97-98.

36. Raynal, Histoire des deux Indes, vol. V, chap. I4, 197-98. Aravamudan refers to this story in a note that addresses representations of colonized females; see Tropicopolitans, 408 n35. See also Peter Hulme, Colonial Encounters: Europe and the Native Caribbean, 1492-1797 (New York: Methuen, I986), 225-63. The trope of the indigenous woman saving the life of the European colonist has been common since the sixteenth century and is embodied in the figures of la Malinche or Pocahontas for example. By the nineteenth century, it becomes a foundational narrative in South American literature, especially with a mixed raced offspring left behind (see for instance the Brazilian novel by José de Alencar, Iracema from I865). The stillbirth of Stellina's child in Lucien Bonaparte's novel signals the narrator's choice that England shall not set a genealogical foundation in Ceylon.

37. I would argue that sentimental affect works differently in La Tribu indienne, which turns suffering into spectacle, than in Histoire des deux Indes, where the story of Inkle and Yarico (and numerous other examples) proffers evidence for the colonial trauma and abuse denounced by Diderot, though a more detailed analysis remains to be done inspired by Ramesh Mallipeddi's Spectacular Suffering: Witnessing Slavery in the Eighteenth-Century British Atlantic (Charlottesville, VA: University of Virginia, 20I6).

38. Douthwaite, review of "La Tribu indienne, ou, Édouard et Stellina," Eighteenth-Century Fiction 23, no. I (Fall 20I0): 254.

39. Douthwaite, review of "La Tribu indienne," 255. 
instead of the standard three points of suspension. These longer, multiple ellipses suggest the senses are overpowering speech:

Cette figure enchanteresse, .... ce sein découvert, .... Cette taille élancée couverte ici d'un voile transparent, et là dans tout l'éclat de la nudité, ... . Tout remplit à la fois les yeux et l'âme du jeune homme. . . . Il se prosterne, et un cri d'admiration lui échappe.

[This enchanting figure, .... this uncovered breast, . . . this narrow waist here covered by a transparent veil, and there in all the splendor of its nakedness, . . . they all fill at once the young man's eyes and soul .... He falls on his knees and a cry of admiration escapes him].

Awakened and quick to seize bow and arrow to kill the sacrilegious stranger, Stellina instead spares a body she sees as suffering, moved by "la larme du désespoir [qui] roule sur sa joue décolorée" [the tear of despair rolling on his discolored cheek] (34). Because the customary power relations are reversed, the native woman holding the colonizer's life in her hands at the onset of the story and displaying humanity and sympathy, Édouard's choice to sacrifice his savior in the end confirms the narrative's indictment of British exploitation and inhumanity. Such condemnation, however, is undermined by the manner in which the narrator indulges in several voyeuristic episodes that depart from the sentimental to cross into a libertine vein that was in vogue in the eighteenth century. First, there is the scene of Stellina's sexual arousal in the waters of the creek culminating with her solitary “jouissance," inspired by Bernardin de Saint-Pierre's Virginie's night bath, but made explicit (64). A few pages later, the codes of a traditional pastoral scene of male seduction are mixed with a libertine representation of intercourse whereby Édouard's sexual performance turns Stellina's defloration into a strange sexual marathon (65-66). At this point, the narrator's multi-dots ellipsis seems to mimic uninterrupted coitus:

Et en soupirant la dernière parole, il se penche sur le sein de son amante, et le sacrifice amoureux se renouvelle . . . . . . . . . . . .

La grotte, pendant ce jour, ne résonna que des accens de la volupté.

[As he sighs the last words, he leans toward his lover's breast, and love's

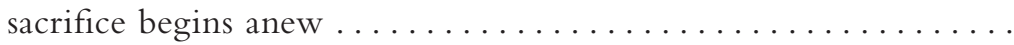

On this day, only echoes of voluptuousness resounded in the cave.] 
Later on in the novel, as danger has passed for Édouard, as the attraction of Stellina's body has worn off, as her beauty declines under the burden of distress- " plus que des charmes flétris" [only withered charms] (93)—Édouard negotiates their fate with the Portuguese. The bodies of courtesans are offered to his appetite, just as they serve the Portuguese who trade them. Readers are treated to another short libertine scene, multiplied by mirrors, between the Portuguese viceroy Fuentes and the most renowned courtisane, the Spaniard Léonice (90). In the Indian 'seraglio,' so to speak, of his ally count Arpos, naked female slaves serve the Portuguese count and his friends. In keeping with one of the connotations of commerce as illicit relations between opposite sexes, all examples so far confirm that carnal exchanges between European and local inhabitants transgress moral rules, here to appropriate better the conquered land. Raynal had noted the dissolution of Portuguese chivalrous character into increased corruption, an aspect of which is sex trafficking or prostitution:

Ils avoient la plupart, sept ou huit concubines, qu'ils faisaient travailler avec la dernière rigueur, $\&$ auxquelles ils arrachaient l'argent qu'elles avoient gagné par leur travail. Il y a loin de cette manière de traiter les femmes, aux mœurs de la chevalerie.

[Most of them had seven or eight concubines, whom they forced to work with the utmost severity, then took the money their work had earned them. Such treatment of women was a long way from chivalric mores. $]^{40}$

Lucien Bonaparte turns the passage into a tableau exemplary of the orientalism Edward Said exposed in other works:

Parmi celles dont la blancheur éblouit, quelques Africaines à l'œil brûlant, aux lèvres de corail, aux dents de neige, présentent des appas robustes sur des corps d'ébène. Ces nuances diverses varient la jouissance, et les filles d'Afrique sont préférées souvent par les jeunes Portugais, qui, revenus de leurs préjugés, savent qu'un tempérament de feu fait oublier la couleur. ...

[In the midst of those women whose whiteness dazzles, several African women with burning eyes, coral lips, and teeth like snow offer ebony bodies robustly endowed. These diverse nuances help vary pleasures and Africa's daughters are often preferred by young Portuguese, who, having shed their prejudice, know that a fiery temperament makes one forget color. ...]

40. Raynal, Histoire, vol. I, chap. 24, I3I. 
The writing of such an exotic scene casts suspicions upon the novel's moral and political outrage as it exploits, narratively speaking, the very bodies it might seem to want to defend ideologically.

Lucien Bonaparte plucked his female character Stellina out of Raynal, who himself took it from Steele, who had discovered it in an old travel narrative, Richard Ligon's A True and Exact History of the Islands of Barbadoes (I656). In this way Stellina is further emptied of subjectivity and agency: she becomes the vehicle for moralizing about the colonial actor. Lucien Bonaparte's Stellina is construed as a victim of colonial greed: naïve, loyal, pathetic, her body eventually traded by her lover in exchange for gold. Even before this commercial deal, Édouard's sexual attraction conflates with attraction to the wealth he imagines she possesses as heiress to her elderly father. The Portuguese want her hostage so they can negotiate land and a peace treaty with her tribe, though they do not know that, by losing herself to a foreigner, she has lost all her value in her tribe's eyes and is in fact condemned to death. Her subjugation is physical, sentimental, and mental, as she becomes prey to the tribe's Brahma whose manipulations propel the plot into a downward spiral of murders and warfare.

Lucien Bonaparte closed his novel with a few lines dedicated to his sister Eléonore, writing: "La soif immodérée des richesses étouffe la nature, et l'or appelle tous les maux sur la terre qui le renferme" [Immoderate thirst for riches chokes nature, and gold attracts all wrongs to the grounds that holds it] (II 4). The morality of this lesson was deployed in one engraving in Raynal's Histoire des deux Indes (which contributed to the story's popularity) and by five illustrations in Lucien Bonaparte's novel, which served to channel sentimentality from the story to the reader and back. ${ }^{4 \mathrm{I}}$ Whereas the author's moral lesson shapes Stellina as an allegory that embodies the fall of nature to corrupting civilization, a pathetic victim of colonial greed, the narrative can only flesh Stellina out by turning her body into an orientalist phantasm, an object of desire, which clashes with her figuration as a universal allegory of suffering.

4I. The first edition included five engravings by Barthélemy Roger and Jean Godefroy, from Pierre-Paul Prud'hon's drawings. They are reproduced in Feilla's edition (I8-22) and analyzed by Feilla in "From Periphery to Centre: The Global Contexts of Prud'hon's Illustrations for La Tribu Indienne, Ou Édouard Et Stellina (I799)" in Book Illustration in the Long Eighteenth Century: Reconfiguring the Visual Periphery of the Text, ed. Christina Ionescu (Newcastle upon Tyne, England: Cambridge Scholars, 20II), 265-94. For a reproduction and analysis of the two illustrations that represent the anecdote of the Englishman from Barbados selling his liberator/mistress in Raynal's illustrated Histoire, see Lise Andries, "Les Illustrations dans l'Histoire des deux Indes," in L'Histoire des deux Indes: réécriture et polygraphie, 27-28. The first engraving of this "évènement atroce" [atrocious event] was the frontispiece of Raynal's book V (see https://artflsrvo3.uchicago.edu/philologic4/raynal/navigate/II/I/, and specifically https://artflsrvo3.uchicago.edu/philologic4/raynal/images/raynal_I774_5_oo4.jpg). The second engraving appeared in all illustrated editions. 


\section{Religious Commerce}

Unlike the more ambivalent political and sexual commerce in the story, religious commerce or, to put it otherwise, the Brahma's trafficking in religious influence within his tribe (for instance when he manipulates a naïve Stellina) is condemned without ambiguity. The last paragraph of the novel concerns the fate of the Grand Brahma Deli, who in retrospect appears as Lucien Bonaparte's most malevolent, duplicitous character. A universalizing last sentence accuses all priests of the world of perpetrating crimes and spreading lies:

Le grand-brame vécut encore long-tems, mais en butte aux soupçons de Cosmoë; au lieu du sceptre, il n'obtint que le mépris et l'impuissance. . . . Dans tous les pays de la terre, les prêtres sont les artisans du crime et de l'erreur.

[The Grand Brahma lived on for a long time, but exposed to Cosmoë's suspicion; instead of a scepter, he received but contempt and no power. ... In all countries of the earth, priests are the artisans of crime and error.]

Introduced as an ambitious, calculating character, the Brahma is a man who hates Europeans and who shares authority with the king Itobar Ditulan, Stellina's father, over the Ténadares tribe. Passing for an oracle, he manipulates a so-called "génie du mal" to pressure Stellina to choose a spouse among her tribe, a choice that provokes a feud among several chiefs aspiring to her hand. The Brahma, who had wanted her to wed his nephew, foments the assassination of his nephew's rival Riamir. As the sentence quoted above generalizes from one Indian Brahma to all priests, its young author's anticlerical voice could not be clearer. Inheritor of Voltaire's "Écrasez l'infâme," of Diderot's relentless critique, and of the Revolution's attacks against the clergy, Lucien Bonaparte turns the Brahma into "l'infâme," a stand-in for all religious and spiritual mystifications exploiting people's fears and credulity to yield power and influence. The Church that stands accused in the novel is indirectly the one that, in the name of Christianization, forcefully colonized the minds of indigenous populations in support of the larger European conquest, but also the Church at home that interfered for so long in politics, amassed riches, and yielded considerable power - the Second Estate that the Revolution attempted to break apart.

It is hard to say how contemporary readers who had access to the novel reacted to its unambiguous anticlericalism. In the circle and famous salon of Juliette Récamier, to the ears of contemporaries like Germaine de Staël and François-René de Chateaubriand, not to mention Lucien's brother 
Napoleon, it was probably too strident to be acceptable. It was also coming too late to be useful: there was by then a consensus that restoring the Catholic cult was the best strategy to reunite and appease a country still under the double shock of I789 and the Terror. Lucien Bonaparte was eventually convinced by an agenda that promoted social and religious restoration against the "specter of atheist Jacobinism"; ${ }^{22}$ he might have wanted to recant his anticlerical profession of faith (and his confused stylistics) by disclaiming a book now passé since the success of Chateaubriand's novella Atala (I80I) and Génie du Christianisme (I802), which celebrated the beauties of Christianity in a prose that enchanted all contemporaries. When his Consul brother named him to the Tribunat in I802, Lucien defended the project of reconciling with Rome and the text of the Concordat signed later that year. The Pope's support of, and friendship with, Lucien Bonaparte turned out to be essential when the latter chose exile in Italy in the wake of Napoleon's increasing powers: his dictates upon his siblings' choice of spouses, including Lucien's, his execution of the Duke d'Enghien (March I804), and his self-proclamation as Emperor (May I804).43 Without the novel we would have no trace of Lucien Bonaparte's reversal from an anticlerical to pro-religious stance certainly fueled by self-interest, political ambition, peer pressure, and his brother's orders, but also symptomatic of the strategies on how to reinstate religious "commerce" between the Catholic Church and a post-revolutionary France.

\section{Literary Commerce: Crossing Sentimental and Epic}

Of the many traffickings that happen in La Tribu indienne, one of the most manipulative may be aesthetic because it compromises the genre of the narrative. The global commerce of gold and precious stones, of indigo and spices-cloves, nutmeg, cinnamon-is the realistic background to a narrative that also traffics in literary genres: the sentimental, the exotic, the pastoral, the libertine, the gothic, and the epic. While confusion in genres can often signal productive experimentations, such is not the case here. Instead, the manipulation of generic codes reveals conflicting literary appropriations of early modern classics whereby the author tries to compete in a post-revolutionary European literary field in his search of a French national epic. The confluence of sentimental and epic was a utopian literary ideal pursued by French authors like Marmontel and Chateaubriand to name the most prominent, in imitation of the dialectics between romance and epic in Ariosto's Orlando Furioso (also a favorite

42. Jean-Claude Berchet, "Le Mercure de France et la 'Renaissance' des lettres," in L'Empire des Muses. Napoléon, les Arts et les Lettres, ed. Jean-Claude Bonnet (Paris: Belin, 2004), 42 .

43. Simonetta and Arikha, Napoleon and the Rebel, I60. 
of Napoleon) and Tasso's much admired Jerusalem Delivered. ${ }^{44}$ Lucien Bonaparte's narrative alternates between epic episodes, gothic vignettes, lyrical descriptions characteristic of the genre of "exotic pastoral" so successfully imagined by Saint-Pierre's Paul et Virginie, and lyrical dialogues imbued with so-called "primitive eloquence." 45

The pastoral vein in the novel does not escape the sexualization I described earlier with regards to the characters. Like Saint-Pierre's eroticized landscape of the Bourbon island in the eighteenth-century best-seller Paul et Virginie, the narrator's initial tableau of Ceylon abounds with sexual analogies. The island emerges, Venus-like, out of the ocean; an aptly named "pic d'Adam" (Adam's peak) rises like a dominating white phallus toward the sky:

L'île de Ceylan ... semblait d'abord sortir avec modestie du sein de l'Océan, s'élever ensuite avec majesté sur la surface, et bientôt braver orgueilleusement les vagues écumantes. ... Les pitons sourcilleux et blanchâtres du pic d'Adam frappaient sur-tout les regards du jeune homme, peu accoutumés à ce sublime spectacle. . . Le pic d'Adam, la plus élevée des montagnes des Indes, qui s'élance au milieu de Ceylan jusqu'aux nues, semble d'une part dominer la mer indienne, et de l'autre le golfe du Bengale.

[The island of Ceylon ... seemed at first to emerge modestly from the ocean's bosom, then it rose majestically from the surface, and soon proudly defied foaming waves.... The supercilious, whitish tops of Adam's peak particularly struck the young man's eyes, little accustomed to such sublime spectacle. . . Adam's peak, India's highest mountain, which rises from the midst of Ceylon toward the skies, seems to dominate, on the one hand, the Indian ocean, and on the other, Bengal's gulf.]

The narrator's trademark ellipses seem to create pauses to process the description's double-entendre: adverbs like "modestement" [modestly] and poetic epithets like "sourcilleux" [supercilious] clearly gender the landscape; it is also racialized so to speak- the "pitons blanchâtres" contrasting with the "mer indienne"; moreover, a Biblical narrative projected onto the landscape

44. See Sergio Zatti, The Quest for Epic. From Ariosto to Tasso (Toronto: University of Toronto Press, 2006). Alexandre Cioranescu concludes his study with the suggestion that "l'épopée napoléonienne," namely Napoleon's life of military and sentimental conquests, drew inspiration from Orlando Furioso. See Cioranescu, L'Arioste en France, des origines à la fin du XVIIIème siècle (Paris: Les Presses modernes, I938), 2:I87.

45. Additional French sources include Marmontel's epic prose poem, Les Incas ou la destruction de l'empire du Pérou (I777), and Chamfort's one-act comedy La Jeune Indienne (I754). On Chamfort, see Feilla's introduction, La Tribu indienne, 9-IO and II5 n2. 
Christianizes the tropics: the ship captain Rinéald explains to Édouard that Natives believed that Paradise was located on the mountain, claiming they could show Adam's footprint.

Lucien Bonaparte borrows from the pastoral genre in fashioning an Eldorado of vegetal and mineral riches and beauty. But while Saint-Pierre's description of nature's paradisiacal abundance on the Bourbon island was not explicitly linked to colonial trade, La Tribu indienne emphasizes right away the value of Ceylon's natural resources as commodities at the ready for an economy of extraction:

Quant aux productions de l'île, elles sont précieuses. Les cocos, les oranges, les limons y sont délicieux; le bétail, les oiseaux y abondent. Le pays est couvert de forêts où se recueille la canelle. Les diamans, saphirs, escarboucles, topazes, grenats y sont les plus beaux de l'Orient. On y fait une pêche abondante de perles; les montagnes renferment beaucoup de mines d'or et d'argent.

[As far as the island's productions are concerned, they are precious. Coconuts, oranges, and lemons are delicious; game and birds abound. Forests where one collects cinnamon cover the country. Diamonds, sapphires, carbuncles, topaz, and garnets are the most beautiful in the Orient. The fishing of pearls is abundant; the mountains hold lots of gold and silver mines.]

Imitating Saint-Pierre who inserted the names of local plants unknown to Europe to defamiliarize his readers and create poetic effects, Lucien Bonaparte tries to poeticize his prose with exotic names qualified by epithets, for instance when Stellina saves Édouard by telling him: “Je te donne jusqu'à demain pour réparer tes forces. Les cocos nourrissants, les albêtres aux fruits rouges ciselés, les sagoux farineux t'environnent, et l'eau désaltérante est près de toi." [I give you until tomorrow to regain your strength. Nourishing coconuts, the red, chiseled fruit of the albetre, the mealy sago are all around, and refreshing water near you] (35). Later on, during their escape from Stellina's tribe, the pace of the frantic pursuit slows down for a sentimental, pastoral moment fraught with symbolic Biblical reminiscences beneath the exotic, local botanical terms:

Hors de leur atteinte, ils étaient assis sur la colline de Movéa, où le paradigge et le jombos étaient leurs fruits succulens. Du milieu de ces arbres peu élevés s'élancent le vellas et le jack, dont la tête verdâtre est hérissée d'épines: d'autres arbres portent des pommes qui par le jus et la saveur, ressemblent l'ananas. Le bas du monticule est couvert de petits cocotiers que l'on préfère à tous les autres pour fabriquer l'étoffe 
de caros.... Dans un clin d'œil la jeune Indienne apprête le repas. Édouard reçoit de ses mains la pomme champêtre qu'il ne connaissait point encore; il en savoure le jus délicieux.

[Safe from their reach, they sat on the hill of Movéa, where the paradigge and jombos were their succulent fruit. From the middle of these trees, short in size, rise the vellas and the jack, which has a greenish, prickly head; other trees produce apples with a juice and taste resembling pineapple. The bottom of the hill is covered by short coconut trees that are favored among all others to make the caros cloth ... In the twinkling of an eye, the young Indian girl prepares their meal. Édouard receives from her hand the pastoral apple, which he did not yet know; he savors the delicious juice.]

Lucien Bonaparte added a note to help readers imagine (or taste) the meal by comparing the fruit with known European varieties, pears, apples, cabbage, and chestnuts (II7). The accumulation of local names and precise botanical descriptions in the passage seek to emulate Saint-Pierre, via the eighteenth-century naturalist Buffon, to create a realistic yet poetic background to the story. ${ }^{46}$ But when the narrator has Stellina offer "la pomme champêtre" to her lover who had never tasted it before, this Garden of (Eastern) Eden becomes the site of an original sin that turns the native woman into the first sinner, the guilty temptress, in complete reversal of the story's seduction plot, but perhaps in keeping with her first experience of solitary pleasure. Whereas Saint-Pierre's heroine Virginie chooses to drown and preserve her virginity, the premature birth of Édouard's child causes Stellina's agonizing death. Ultimately, Lucien Bonaparte subverts Saint-Pierre's representation of erotic love dignified by nature and never to be consummated: far from Saint-Pierre's aesthetics and politics of conservation (what Richard H. Grove called his "green imperialism"), ${ }^{47} \mathrm{La}$ Tribu indienne portrays consumption of nature and of sex for the sake of capital accumulation.

The noir pastoral is actually folded into an epic structure, divided into ten "books," in lieu of customary (more prosaic) chapters, each titled with one word meant to project poetic density into the narrative: L'Hospitalité, Le Sacrifice, L'Oracle, La Discorde, La Grotte, Le Meurtre, La Fuite, L'Ingratitude, La Vengeance, La Conquête. Characteristic epic markers include

46. On Saint-Pierre's lyrical attention to plants, see Joanna Stalnaker, The Unfinished Enlightenment: Description in the Age of the Encyclopedia (Ithaca, NY: Cornell University Press, 20I0).

47. See Grove, Green Imperialism: Colonial Expansion, Tropical Island Edens, and the Origins of Environmentalism, 1600-1860 (Cambridge: Cambridge University Press, 1995), chap. 5, I68-263. 
the harangues of the tribal chief $(40,57)$, internal divisions and rivalry (59), the plotting of warfare (68), and the funeral pyre. Among stylistic traits recurrent in eighteenth-century epics in prose, we find indicating time with the sun; ${ }^{48}$ accelerating time with the adverb "déjà;" the closing of oral proclamations with "il dit" (7I; II3); the anteposition of epithets; ${ }^{52}$ and epithets associated with characters- "le superbe Riamir" (43), "Ipénare à la tête blanchie" (60), "le farouche Cosmoë" (62). The accumulation of these distinctive traits points to the author seeking to orient his novel toward a primitive prose epic like Ossian by the Scottish McPherson, an influential model since its translation by Le Tourneur in I777, notwithstanding the controversy over its authenticity. One of the most distinctive features of La Tribu indienne is its paratactic style, short sentences juxtaposed without coordination, which seek to capture a primitive eloquence similar to Ossian. Metaphors like "bouche à feu" for canon (I IO) that describe literally a modern object offer additional clues of a style emulating a primitive parole that does not know the proper name of modern European technological inventions. ${ }^{53}$ Here is one short example of a melancholy tone, rhythmic structure, and simile that suggest strong Ossianic reminiscences, down to the character's name ending in -or :

Mais aujourd'hui Riamir et Cosmoë ne sont plus, et Ténor, privé de ces braves, ressemble au troupeau que les chiens vigilants ont abandonné: les loups pénètrent dans le bercail, sans qu'aucune voix ait donné l'éveil au pasteur endormi, qui devient la victime de son innocence.

48. "Depuis long-tems le soleil éclairait l'île de Ceylan" [The sun had been shining on the island of Ceylon for a long time] (54); "Le soleil avait à peine parcouru la moitié des cieux" [the sun had barely run half its course in the sky] (59); "À l'heure où le soleil achève sa course, tout le peuple arriva" [At the hour when the sun ends its course, the people arrived] (73).

49. "Déjà les trois Européens sont traînés auprès du bûcher qui va les recevoir lorsqu'un bruit confus s'élève vers le midi" [Already, the three Europeans are dragged to the pyre which is about to receive them when a confused noise rises towards the south] (4I).

50. "La Discorde éloigna le sommeil des bords de la Sanga" [Discord chased sleep from the banks of the Sanga river] (58).

5 I. "les rugissemens des monstres sauvages [sont] moins terribles que leur silence" [the roaring of these wild monsters is less terrible than their silence] (73). "A ce cri plus odieux que celui du tigre, [Caliture] répond par d'affreux rugissemens, se précipite dans les flots, lutte contre eux, et s'élance sur le rivage" [To this cry more odious than the tiger's, (Caliture) responds with dreadful roaring, jumps into the water, fights against the current and runs up the shore] (77).

52. "Ainsi se retrempent en même tems et dans les même lieux les armes mortifères et les féroces courages" [Thus deadly weapons and ferocious courage are quenched at the same time in the same place] (59).

53. Lucien Bonaparte possibly borrowed "bouche de feu" for canon from Évariste Parny's prose poems Chansons madécasses ( 1787 ): it is the only metaphor within Parny's famous collection. 
[But today Riamir and Cosmoë are no more, and Tenor, deprived of these brave men, resembles the herd that vigilant dogs have abandoned: wolves enter the sheep-pen without a voice waking up the sleeping shepherd, who becomes the victim of his innocence.]

The fact that wolves, shepherds, and their dogs are an unlikely presence on the island of Ceylon comically exposes La Tribu indienne's odd discursive mélange. Further, the intrusion of two gothic episodes disrupts the Ossianic, melancholy atmosphere the author attempted to emulate, namely Stellina's graphic premonitory dream of Édouard's bloody death (54-55), preceded by the episode of her midnight visit to the temple, orchestrated by the Brahma, who deceives her senses with an acoustic and visual mise en scène of the sacred that is so ghostly as to cause her to faint $(5 \mathrm{I}-52)$.

One historical character in the text embodies the alliance of epic and sentimental tropes, namely the Portuguese viceroy Fuentes, whom the narrator portrays as a paternalistic colonial leader, sensitive to Stellina's fate, reluctant to wage unjust wars but firm when in battle, eager for cooperation and peace with the natives. Fuentes is a prototype of alternative diplomacy with indigenous people and of leadership that believes in mutual respect for mutual commercial benefit. The more positive characterization of the Portuguese leader as a heroic yet sentimental warrior might reflect the general thrust of Raynal's chapter on the rise and decline of the Portuguese in the East Indies: Raynal had underlined the valor of the Portuguese and the heroic character of their maritime adventures, the better to delineate their gradual downfall into pleasures and "mollesse." ${ }^{54}$ Lucien Bonaparte condensed into one man, Fuentes, the prototype of early Portuguese conquerors with later corrupted Portuguese colonizers. In waging war, Fuentes's actions hark back to his ancestry; but in the arms of his favorite courtisane, he illustrates Raynal's chapter on "Corruption des Portugais dans l'Inde" [Portuguese Corruption in the Indies]. ss Though less a failure than Édouard's mercantile pursuits, which ultimately lead to his death, Fuentes's colonial strategy is manquée and will not resist another attack by the coming Dutch, as the end of the novel predicts.

How would contemporary readers have read the trading of epic and sentimental genres in the story? I surmise they would have recognized Lucien Bonaparte's gesture toward the Portuguese epic poem of "discovery"/conquest, Camoëns's The Lusiads (I572), which alternated descriptions of battles with lyrical outpourings. By the end of the eighteenth century, debates about epic poetry increasingly and favorably invoked Camoëns's The Lusiads,

54. See Raynal's chapter "Les Portugais s'amollissent \& ne sont plus redoutables" [The Portuguese are getting soft \& are no longer feared], Histoire, vol. I, chap. 26, I34-35.

55. Raynal, Histoire, vol. I, chap. 24, I3I. 
Ariosto's Orlando Furioso (I5I6), Tasso's Jerusalem Delivered (I58I), and Ossian's Fingal to praise a mélange of genres that French purists like Boileau had downgraded in his landmark i67I Art poétique. Impatient to modernize French literature and conquer the literary field, the twenty-four-year-old Lucien Bonaparte avidly appropriated past and present sources, making La Tribu indienne a paradigmatic colonial fiction where the letter is as compromised as the spirit. Lucien Bonaparte's borrowings from, or commerce with, European winning epics in order to carve a prose epic set in East India, confirm the epic genre as a vector for empire building. But as Festa demonstrated, sentimentality was also needed to offset the violence and exploitation that imperial conquests entailed..$^{56}$

Following his sentimental prose epic on Ceylon, Lucien Bonaparte published an epic poem in verse in twenty-four songs, Charlemagne; ou L'église délivrée; poème épique, en vingt-quatre chants (I8I4). Another, La Cirnéide ou La Corse délivrée des sarrasins. Poème épique en douze chants (I8I9), harkens back to Napoleon's own attempt to write a colonial history of Corsica in I789, inspired by Raynal. ${ }^{57}$ Lucien Bonaparte's national epic poems on Charlemagne and on Corsica (both "delivered" from non-Christians) confirm the author's ambition to compete in the literary field in what remained, even at the dawn of the nineteenth century, a frustrating quest for a modern French epic poem worthy of the ancients and on a par with Portuguese, Italian, Spanish, and British epic poems. A painting makes the point: the most famous portrait of Lucien Bonaparte (by Fabre in I808) represents him holding a copy of Tasso's Jerusalem Delivered..$^{8}$

"The Messy Legacies of Empire"

A discursive disorder dominates Lucien Bonaparte's La Tribu indienne, ou Édouard et Stellina. From an aesthetic point of view, the novel is manqué, to echo the "politics manqué" 59 noted by Aravamudan in colonialist representations: its style is awkward; its exoticism clichéd; the narration abrupt and disjointed, with abundant ellipses; its poetic effects less original than imitative; the

56. I suggest that Festa's argument on "sentimental figures of empire" can be deployed to interpret European epics such as Camoens's, Ariosto's, Tasso's, and Ossian's.

57. In I789, an admiring 20-year-old Napoleon had met with 76-year-old Raynal to discuss a project of writing a history of Corsica, paying homage to the spirit of a small people fighting for its independence. Feeling encouraged, he sent him his first two "Letters on Corsica" in I790, but the project stopped when an important source, the famed Corsican Paoli, refused to communicate documents. See Napoleon, Manuscrits inédits. 1786-1791, ed. Frédéric Masson and Guido Biagi (Paris: Société d'éditions littéraires et artistiques, 1907), 395-445 and 38I-89 for Napoleon's unfinished novel on Corsica.

58. For an analysis of the painting and its sitter's investment in epic poetry, see Caracciolo, "Portrait d'un home tenant un livre," in 1775-1840, 30I-7.

59. Aravamudan, Tropicopolitans, 9. 
characters' development is schematic; the codes of the epic, sentimental, and libertine genre are juxtaposed self-consciously. These flaws offer clues to the narrative's vacillations: as is often the case with so-called minor works, Lucien Bonaparte's novel exposes ideological tensions characteristic of its times, in a manner more transparent for being naïvely executed. The text oscillates between a literary representation of colonial relations and commercial practices, on the one hand, and, on the other, an embedded critical rejection of the exploitations of resources and people that mercantilism implied.

That the form and substance of the narrative is so troubled is no coincidence as it has a difficult time representing its subject matter and making choices. As Aravamudan reminds us: "Though some critics would have us choose between hybridity and authenticity, or collaboration and opposition, the messy legacies of empire do not always afford such clear-cut choices. One manifestation of agency may look like assimilation, incremental change, or liberal reformism. . . . For all these reasons, none of these figures can be readily characterized as colonialist villains or anticolonial heroes." ${ }^{\circ 0}$ Such representations are also born of men caught in history's flux: for Jean-Claude Berchet, "Les disparates [de Lucien Bonaparte] sont caractéristiques de cette phase de 'sortie' de la Révolution où les aspirations naturistes, les rêveries sentimentales, voire le radicalisme politique viennent poétiser le brutal arrivisme du parvenu avide de pouvoir, de faste, de richesses" [Lucien Bonaparte's contrasts are characteristic of the "exit" phase of the Revolution, when yearning for nature, sentimental reveries, and even political radicalism help poeticize the brutal ambition of the parvenu, thirsty for power, pomp, and luxury. $]^{61}$

We do not have many testimonies to evaluate the reception of the book in I799, though Lucien Bonaparte's social circle certainly remembered this confused "œuvre de jeunesse" penned by the brother of the future first Consul and soon disavowed. ${ }^{62}$ Because its confusion captures the ideological ambiguities at work in Raynal's Histoire des deux Indes, a history of colonial trade ventriloquizing

6o. Aravamudan, Tropicopolitans, I4. Emphasis added.

6I. Berchet, "Le Mercure de France et la 'Renaissance' des lettres," in L'Empire des Muses, 25 .

62. Chateaubriand indirectly revived it in his Mémoires d'outre-tombe (I849-50). In his "Fragments retranchés: 'Le livre sur Madame Récamier," we find a portrait of Lucien Bonaparte by Chateaubriand, followed by the copy of a love letter Lucien addressed to Juliette de Récamier, with whom he had fallen in love after meeting her in summer I799. The love letter is a 'fiction' titled "Lettre de Roméo à Juliette par l'auteur de la Tribu indienne" (emphasis added) in the same sentimentalist vein as the novel. Chateaubriand comments : "Pour un homme de sang-froid, tout cela est un peu moquable: les Bonaparte vivaient de théâtres, de romans et de vers: la vie de Napoléon lui-même n'est-elle autre chose qu'un poème?" [For a man of sang-froid, this is all quite laughable: the Bonapartes lived off plays, novels, and verses: isn't Napoleon's life itself but a poem?] François-René de Chateaubriand, Mémoires d'outre-tombe, ed. Jean-Claude Berchet (Paris: Garnier, 1989-98), 2:I295-97. 
Diderot's anticolonial and anticlerical eloquence, La Tribu indienne matters to understand the development of a generation of French Romantic intellectual and political figures, contemporaries like Chateaubriand, Germaine de Staël, and Napoleon, all readers of Raynal.

University of Oregon

\section{Bibliography}

Agnani, Sunil. Hating Empire Properly. The Two Indies and the Limits of Enlightenment Anticolonialism. New York: Fordham University Press, 2013.

Andries, Lise. "Les Illustrations dans l'Histoire des deux Indes." In L'Histoire des deux Indes: réécriture et polygraphie, edited by Hans-Jürgen Lüsebrink and Anthony Strugnell, II-4I. Studies on Voltaire and the Eighteenth Century series, no. 333. Oxford: Voltaire Foundation, I995.

Aravamudan, Srinivas. Tropicopolitans. Colonialism and Agency. 1688-1804. Durham, NC: Duke University Press, I999.

Benot, Yves. La Démence coloniale sous Napoléon. Paris: La Découverte, 2006.

—. Les Lumières, l'esclavage, la colonisation. Paris: La Découverte, 2005.

Berchet, Jean-Claude. "Le Mercure de France et la 'Renaissance' des lettres." In L'empire des Muses. Napoléon, les Arts et les Lettres, edited by Jean-Claude Bonnet, 2I-58. Paris: Belin, 2004.

Bonaparte, Lucien. Charlemagne; ou L'église délivrée; poème épique, en vingt-quatre chants. 2 vols. Rome: F. Bourlié, I8I4.

__ La Cirnéide ou La Corse délivrée des sarrasins. Poème épique en douze chants. Paris: Firmin Didot, I8I9.

. Les Ténadares ou l'Européen et l'Indienne, traduit de l'anglais de mistriss Helm, auteur de la caverne de sainte Marguerite, par Mr. A.C. 2 vols. Paris: Chaumeront aîné, I822. https://gallica.bnf.fr/ark:/I2I48/bpt6k5509632I.

. La Tribu Indienne, Ou Édouard Et Stellina, par le citoyen L. B. Paris: Honnert, an VII [1799].

La Tribu Indienne, Ou Édouard Et Stellina. In Veillées littéraires illustrées, edited by Jean Bry. Paris: Hachette Livre - BnF, I849. https://gallica.bnf. fr/ark:/I2I48/bpt6k5696663c.

—_. La Tribu Indienne, Ou Édouard Et Stellina. Edited by Feilla, Cecilia A. London: Modern Humanities Research Association Critical Texts, 2006. 
Bonaparte, Napoléon. Clisson et Eugénie. Edited by Émilie Barthet and Peter Hicks. Paris: Librairie Arthème Fayard, 2007.

- Manuscrits inédits. 1786-1791. Edited by Frédéric Masson and Guido Biagi. Paris: Société d'éditions littéraires et artistiques, I907.

Caracciolo, Marie Teresa, and Isabelle Mayer-Michalon. 1775-1840: Lucien Bonaparte, un homme libre. Exposition présentée au Palais Fesh-musée des Beaux-Arts du 26 juin au 27 septembre 20I0. Ajaccio, FR: Palais Feshmusée des Beaux-Arts, 20 Io.

Charara, Youmna, ed. Fictions coloniales du XVIIIe siècle. Ziméo. Lettres africaines. Adonis, ou le bon nègre, anecdote coloniale. Paris: L'Harmattan, 2005.

Chateaubriand, François-René, vicomte de. Mémoires d'outre-tombe. 2 vols. Edited by Jean-Claude Berchet. Paris: Garnier, I989-98.

Chuquet, Arthur. La Jeunesse de Napoléon. Vol. 2, La Révolution. Paris: Armand Colin, I898-99.

Cioranescu, Alexandre. L'Arioste en France, des origines à la fin du XVIIIème siècle. 2 vols. Paris: Les Presses Modernes, I938.

Cole, Juan Ricardo. Napoleon's Egypt: Invading the Middle East. New York: Palgrave Macmillan, 2007.

Cooper, Frederick. Colonialism in question: Theory, Knowledge, History. Berkeley, CA: University of California Press, 2005.

Dictionnaire historique de la langue française. Edited by Alain Rey. Paris: Dictionnaire Le Robert, I993.

Douthwaite, Julia V. Review of La Tribu indienne, ou, Édouard et Stellina, by Lucien Bonaparte. Eighteenth-Century Fiction 23, no. I (Fall 20I0): 253-55.

Duchet, Michèle. Anthropologie et histoire au siècle des Lumières. I97I. Paris: A. Michel, I995.

—. Diderot et L'Histoire des deux Indes ou l'écriture fragmentaire. Paris: Nizet, 1978.

Feilla, Cecilia A. "From Periphery to Centre: The Global Contexts of Prud'hon's Illustrations for La Tribu Indienne, Ou Édouard Et Stellina (I799)." In Book Illustration in the Long Eighteenth Century: Reconfiguring the Visual Periphery of the Text, edited by Christina Ionescu, 265-94. Newcastle upon Tyne: Cambridge Scholars, 20I I.

Ferro, Max. Le Livre noir du colonialisme. XVI-XXI siècle: de l'extermination à la repentance. Paris: Robert Laffont, 2010. 
Festa, Lynn M. Sentimental Figures of Empire in Eighteenth-Century Britain and France. Baltimore: Johns Hopkins University Press, 2006.

Grove, Richard H. Green Imperialism: Colonial Expansion, Tropical Island Edens, and the Origins of Environmentalism, 1600-1860. Cambridge; New York: Cambridge University Press, I995.

Healy, F. G. The Literary Culture of Napoleon. Geneva: Droz, I959.

Hulme, Peter. Colonial Encounters: Europe and the Native Caribbean, 1492-1797. New York: Methuen, I986.

Iung, Théodore. Lucien Bonaparte et ses mémoires, 1775-1840: d'après les papiers déposés aux Archives étrangères et d'autres documents inédits. Paris: G. Charpentier, $1882-83$.

Lüsebrink, Hans-Jürgen and Anthony Strugnell, eds. L'Histoire des deux Indes: réécriture et polygraphie. Studies on Voltaire and the Eighteenth Century series, no. 333. Oxford: Voltaire Foundation, I995.

Lüsebrink, Hans-Jürgen and Manfred Tietz, eds. Lectures de Raynal: L'Histoire des deux Indes en Europe et en Amérique au XVIIIe siècle. Oxford: Voltaire Foundation, I99I.

Mallipeddi, Ramesh. Spectacular Suffering: Witnessing Slavery in the Eighteenth-Century British Atlantic. Charlottesville, VA: University of Virginia Press, 2016.

Martin, Andy. Napoleon the Novelist. New York: Blackwell, 2000.

Martineau, Gilbert. Lucien Bonaparte, prince de Canino. Paris: Éditions France-Empire, I989.

Parny, Évariste Désiré de Forges. Chansons madécasses, traduites en français. In Anthologie de la poésie française, XVIIIe siècle, XIX siècle, XXe siècle, edited by Martine Bercot, Michel Collot, and Catriona Seth, 334-42. Paris: Gallimard, 2000.

Pujol, Stéphane. "Les formes de l'éloquence dans l'Histoire des deux Indes." In L'Histoire des deux Indes: réécriture et polygraphie, edited by Hans-Jürgen Lüsebrink and Anthony Strugnell, 357-69. Studies on Voltaire and the Eighteenth Century series, no. 333. Oxford: Voltaire Foundation, I995.

Racault, Jean-Michel. "L'effet exotique dans l'Histoire des deux Indes et la mise en scène du monde colonial de l'océan indien." In L'Histoire des deux Indes: réécriture et polygraphie, edited by Hans-Jürgen Lüsebrink and Anthony Strugnell, I19-32. Studies on Voltaire and the Eighteenth Century series, no. 333. Oxford: Voltaire Foundation, I995. 
Raynal, Guillaume-Thomas, Histoire philosophique et politique des établissements et du commerce des Européens dans les deux Indes, vol. I, books I-4. Edited by Anthony Strugnell, Rigobert Bonne, and Andrew Brown. Ferney-Voltaire, FR: Centre international d'étude du XVIIIe siècle, 2010.

. Tableaux, atlas et cartes de l'Histoire philosophique et politique des établissements et du commerce des Européens dans les deux Indes: Fac-similés des éditions de 1774 et 1780 . Edited by Anthony Strugnell, Rigobert Bonne, and Andrew Brown. Ferney-Voltaire, FR: Centre International d'étude du XVIIIe siècle, 20 Iо.

- Histoire philosophique et politique des établissements et du commerce des Européens dans les deux Indes. I770; I774; I780. http://artfl-project.uchicago.edu/ raynal-search.

Said, Edward. Orientalism. New York: Vintage, I994.

Saint-Pierre, Bernardin de. Paul et Virginie. Edited by Robert Mauzi. Paris: Flammarion, I992.

Simonetta, Marcello, and Noga Arikha. Napoleon and the Rebel: A Story of Brotherhood, Passion and Power. New York: Palgrave Macmillan, 20 i I.

Stalnaker, Joanna. The Unfinished Enlightenment: Description in the Age of the Encyclopedia. Ithaca, NY: Cornell University Press, 20 Iо.

Strugnell, Anthony. "Dialogue et désaccord idéologiques entre Raynal et Diderot: le cas des Anglais en Inde." In L'Histoire des deux Indes: réeriture et polygraphie, edited by Hans-Jürgen Lüsebrink and Anthony Strugnell, 409-22. Studies on Voltaire and the Eighteenth Century series, no. 333. Oxford: Voltaire Foundation, I995.

Tomiche, Nada. Napoléon écrivain. Paris: Armand Colin, I952.

Zatti, Sergio. The Quest for Epic. From Ariosto to Tasso. Edited by Dennis Looney. Translated by Sally Hill with Dennis Looney. Toronto: University of Toronto Press, 2006. 